\title{
Decreased plasma nociceptin/orphanin FQ levels after acute coronary syndromes
}

\author{
Cs Csobay-Novák ${ }^{1 *}$, P Sótonyi ${ }^{2 *}$, M Krepuska², E Zima ${ }^{1}$, N Szilágyi ${ }^{3}$, Sz Tóth $^{4}$, \\ Z Szeberin², Gy Acsády ${ }^{2}$, B Merkely ${ }^{1}$, K Tekes ${ }^{5}$

\begin{abstract}
${ }^{1}$ Heart Center, Faculty of Medicine, Semmelweis University, Budapest, Hungary
${ }^{2}$ Department of Vascular Surgery, Faculty of Medicine, Semmelweis University, Budapest, Hungary

${ }^{3}$ Department of Physiology and Neurobiology, Institute of Biology, Eötvös Loránd University of Sciences,

Budapest, Hungary

${ }^{4}$ Department of Transplantation and Surgery, Faculty of Medicine, Semmelweis University, Budapest, Hungary

${ }^{5}$ Department of Pharmacodynamics, Faculty of Pharmacy, Semmelweis University, Budapest, Hungary
\end{abstract}

Received: September 1, 2011

Accepted after revision: February 18, 2012

\begin{abstract}
Foregoing researches made on the N/OFQ system brought up a possible role for this system in cardiovascular regulation. In this study we examined how N/OFQ levels of the blood plasma changed in acute cardiovascular diseases. Three cardiac patient groups were created: enzyme positive acute coronary syndrome (EPACS, $n=10$ ), enzyme negative ACS (ENACS, $n=7$ ) and ischemic heart disease (IHD, $n=11$ ). We compared the patients to healthy control subjects $(n=31)$. We found significantly lower N/OFQ levels in the EPACS [6.86 (6.21-7.38) pg/ $\mathrm{ml}]$, ENACS [6.97 (6.87-7.01) $\mathrm{pg} / \mathrm{ml}$ and IHD groups [7.58 (7.23-8.20) pg/ml] compared to the control group [8.86 (7.27-9.83) pg/ml]. A significant correlation was detected between N/OFQ and white blood cell count (WBC), platelet count (PLT), creatine kinase (CK), glutamate oxaloacetate transaminase (GOT) and cholesterol levels in the EPACS group.

Decreased plasma N/OFQ is closely associated with the presence of acute cardiovascular disease, and the severity of symptoms has a significant negative correlation with the N/OFQ levels. We believe that the rate of N/OFQ depression is in association with the level of ischemic stress and the following inflammatory response. Further investigations are needed to clarify the relevance and elucidate the exact effects of the ischemic stress on the N/OFQ system.
\end{abstract}

Keywords: acute coronary syndrome, angina pectoris, nociceptin/orphanin FQ, ischemic stress

More than a decade now that a new chapter has been opened in the research of the opioid system with Mollereau cloning a new member of the opioid receptor family, which was named opioid receptor like orphan receptor (ORL-1) because it was reminiscent of the opioid receptors on both structural and functional ground (21). A year later the endogenous ligand of the ORL-1 was identified and named nociceptin (for its hyperalgesic effect on mice when administered intracerebroventricularly) and orphanin-FQ, because of the Phe and Gln amino acids on the ends of the peptide chain $(21,22)$. The ORL-1 receptor was renamed NOP receptor and the nociceptin/orphanin FQ peptide as N/OFQ in the current nomenclature by NC-IUPHAR.

\footnotetext{
Corresponding author: Prof. Dr. Kornélia Tekes

Department of Pharmacodynamics, Faculty of Pharmacy, Semmelweis University,

Nagyvárad tér 4, H-1089 Budapest, Hungary

Phone: +36 1-2104411; Fax: +36 1-2104400; E-mail: drtekes@gmail.com

* Both authors contributed equally to this work.
} 
NOP receptor shares a high degree of nucleotide sequence homology with each of the cloned $\mu$-, $\delta$ - and $\kappa$-opioid receptors but, most notably, it resembles the $\kappa-1$ subtype (21). However it is naloxone insensitive, unlike all other opioid receptors (7). It is coupled to $\mathrm{G}_{\mathrm{i} / \mathrm{o}}$ protein and it inhibits adenylyl cyclase and $\mathrm{Ca}^{2+}$-influx, and activates $\mathrm{K}^{+}$-efflux in a manner similar to opioids (19). Neuroanatomical studies on rodents have shown that N/OFQ is distributed throughout the central nervous system, especially in regions known to participate in the regulation of autonomic and cardiovascular function (5). A study completed later on humans has shown that there is considerable similarity with the previous findings in the rat central nervous system. The highest concentrations of N/OFQ were noticed in the dorsal central gray matter (periaqueductal gray), the locus coeruleus, the ventromedial nucleus of hypothalamus, the septum and the dorsal horn of the spinal cord. Evidence indicates that N/ OFQ has a significant role in regulating the neurotransmission of the central nervous system (24). There is also evidence that N/OFQ has direct effects on different cardiovascular regulatory areas on rodents both in vitro and in vivo (6). Other study results have shown that N/OFQ has peripheral effects in cardiovascular regulation (12).

In spite of the growing evidence that N/OFQ has a significant role in cardiovascular regulation, studies having been made so far have concentrated mainly on its function in pain sensation and its possible use as a novel analgesic (9). Given that our limited knowledge on the N/OFQ system is based on studies made on rodents, human physiology remains relatively unclear (8). Furthermore, the results of the few human studies are controversial. It seems that the effect of N/OFQ is very much dependent on its dose and way of administration (16). Elevated plasma N/OFQ level was noticed in humans suffering from chronic pain (17), stroke (25), and different chronic liver diseases, such as Wilson's disease (14), primary biliary cirrhosis and hepatocellular carcinoma (15). More recently, Fontana et al. (11) have found that the plasma N/OFQ level rises in patients with spontaneous episodes of angina.

Given that the role of N/OFQ in human cardiovascular pathology becomes more and more focused, our main goal was to examine plasma N/OFQ levels in acute cardiovascular diseases. In this pilot study, we aimed to analyse the effect of severe ischemia on the plasma N/OFQ levels in the groups of enzyme positive acute coronary syndrome (ACS), enzyme negative ACS, and ischemic heart disease patients in a quiescent phase (IHD) and healthy controls.

\section{Materials and Methods}

\section{Patients and diagnostics}

A total of 59 subjects were examined. Twenty-eight of them were admitted to the Heart Center of Semmelweis University (Table I). In 17 cases, acute coronary syndrome was the cause of admission, in which cases admission was immediately followed by taking the patient history and completing a thorough physical examination. Electrocardiography was made to determine if there was an ST elevation $(>1 \mathrm{~mm})$. We used a troponin-T quick test as a specific marker of myocardial necrosis. Blood samples were collected for usual laboratory measurements and enzyme diagnostics (Table II). Laboratory results showed enzyme positivity in 10 cases (study group No. 1: enzyme positive acute coronary syndrome [EPACS], $n=10$ ), the other patients were grouped as having enzyme negative acute coronary syndrome (study group No. 2: ENACS, $n=7$ ). Urgent coronarography was completed in each of the 17 cases by an experienced interventional cardiologist of our institute, who did not participate in this study. Coronarography showed significant stenosis in 15 patients, in which cases 
Table I. Patient characteristics

\begin{tabular}{|c|c|c|c|}
\hline & $\begin{array}{c}\text { Enzyme positive } \\
\text { ACS } \\
(n=10)\end{array}$ & $\begin{array}{c}\text { Enzyme negative ACS } \\
\qquad(n=7)\end{array}$ & $\begin{array}{c}\text { Ischemic heart } \\
\text { disease } \\
(n=11)\end{array}$ \\
\hline Sex (male/female) & $4 / 6$ & $4 / 3$ & $6 / 5$ \\
\hline Age (years) & $71(62-79)$ & $57(52-65)^{*}$ & $75(62-76)$ \\
\hline $\operatorname{BMI}\left(\mathrm{kg} / \mathrm{m}^{2}\right)$ & $23.8(23.5-31.2)$ & $25.3(23.2-34.9)$ & $25.3(23.8-28)$ \\
\hline Systolic pressure (mmHg) & $128(100-140)$ & $132(114-143)$ & $120(112-140)$ \\
\hline Diastolic pressure $(\mathrm{mmHg})$ & $70(50-72)$ & $75(65-79)$ & $70(70-77)$ \\
\hline Heart rate (beats/min) & $80(73-85)$ & $72(65-75)$ & $72(67-81)$ \\
\hline Ejection fraction $(\%)$ & $50(42.5-52.5)$ & $56(55-57.75)^{*}$ & $45(32-55)$ \\
\hline \multicolumn{4}{|l|}{ Risk factors } \\
\hline Previous myocardial infarction & $3(30 \%)$ & $1(14 \%)$ & $5(45 \%)$ \\
\hline Previous PCI & $3(30 \%)$ & $2(29 \%)$ & $7(64 \%)$ \\
\hline Previous stroke & $1(10 \%)$ & $0(0 \%)$ & $2(18 \%)$ \\
\hline Current smoking & $3(30 \%)$ & $2(29 \%)$ & $2(18 \%)$ \\
\hline Diabetes mellitus & $6(60 \%)$ & $1(14 \%)$ & $2(18 \%)$ \\
\hline Hypertension & $9(90 \%)$ & $7(100 \%)$ & $11(100 \%)$ \\
\hline Hyperlipidaemia & $7(70 \%)$ & $4(57 \%)$ & $9(82 \%)$ \\
\hline \multicolumn{4}{|l|}{ Drug therapy } \\
\hline Aspirin & $4(40 \%)$ & $4(57 \%)$ & $6(55 \%)$ \\
\hline Ticlopidine & $1(10 \%)$ & $0(0 \%)$ & $1(9 \%)$ \\
\hline Clopidogrel & $2(20 \%)$ & $3(43 \%)$ & $2(18 \%)$ \\
\hline Oral anticoagulants & $0(0 \%)$ & $2(29 \%)$ & $3(27 \%)$ \\
\hline Beta-blockers & $5(50 \%)$ & $5(71 \%)$ & $6(55 \%)$ \\
\hline Calcium antagonists & $3(30 \%)$ & $2(29 \%)$ & $3(27 \%)$ \\
\hline ACE-inhibitors & $7(70 \%)$ & $5(71 \%)$ & $7(64 \%)$ \\
\hline Angiotensin-II antagonists & $2(20 \%)$ & $3(43 \%)$ & $5(45 \%)$ \\
\hline Nitrates & $2(20 \%)$ & $2(29 \%)$ & $4(36 \%)$ \\
\hline Statins & $5(50 \%)$ & $4(57 \%)$ & $8(73 \%)$ \\
\hline Oral antidiabetics & $4(40 \%)$ & $1(14 \%)$ & $2(18 \%)$ \\
\hline Insulin & $1(10 \%)$ & $0(0 \%)$ & $0(0 \%)$ \\
\hline Diuretics & $4(40 \%)$ & $4(57 \%)$ & $7(64 \%)$ \\
\hline Antiarrhythmics & $3(30 \%)$ & $3(43 \%)$ & $6(55 \%)$ \\
\hline
\end{tabular}

Values are expressed as median (interquartile ranges) or as the number of patients (percentages).

$P$ values show differences compared to the enzyme positive ACS group $\left(p<0.05^{*}\right)$

percutaneous coronary intervention (PCI) was performed immediately. Post-interventional coronarography showed good hemodynamic results. The other 11 patients enrolled in this study were admitted to the Heart Center with a known ischemic heart disease (angina pectoris or myocardial infarction in patient history) in a quiescent phase for a control examination. None of these patients suffered any pain related to their cardiac disease during the previous week of admission. Seven of them underwent elective coronarography, intervention was 
indicated and performed in four cases. All cardiologic patients underwent ultrasonography before being released from the hospital, all completed by the same cardiologist experienced in echocardiography.

Exclusion criteria concluded liver or kidney failure, severe inflammation or malignant disease in patient history, thrombolytic or immunosuppressive therapy and admission after more than 6 hours after the onset of chest pains. A group of 31 healthy people served as the control group, who were not aware of any disease and did not take any medication [15 males, 16 females, age 36.2 (13.8), BMI 24.4 (4.0)]. We obtained a written informed consent from all participants. All patients were managed in accordance with the guidelines of the American College of Cardiology and the American Heart Association (3). The study was conducted in compliance with the ethical standards formulated at the 1983 revision of the Helsinki Declaration of 1975 and its protocol was approved by the Regional and Institutional Committee of Science and Research Ethics of Semmelweis University (205-1/2007).

\section{Blood samples}

For N/OFQ measurements, we collected blood samples two days after coronarography. Samples were collected into vacutainer tubes with K-EDTA as an anticoagulant. Immediately after collection we added $100 \mu \mathrm{l}$ aprotinin $(0.6 \mathrm{TIU} / \mathrm{ml})$ per tube as a protease inhibitor (Calbiochem). Samples were centrifuged at $1600 \mathrm{~g}$ for 15 minutes at $4{ }^{\circ} \mathrm{C}$ using a Janetzky K70 centrifuge. Plasma was transferred into Eppendorf tubes and was stored at $-80{ }^{\circ} \mathrm{C}$ degrees until the measurements were conducted. Sample plasmas were then melted and loaded onto C-18 Sep-Pak cartridges and washed with $0.1 \%$ trifluoroacetic acid (TFA). N/OFQ was eluted with $3 \mathrm{ml}$ of $60 \%$ acetonitrile in $0.1 \%$ TFA, followed by freeze-drying. Validated N/OFQ radioimmunoassay (RIA) was performed at the Department of Pharmacodynamics using a commercially available kit ( $\mathrm{I}^{125}$-NC-RIA, Phoenix Pharmaceuticals, CA, USA) with minimum sensitivity of $1 \mathrm{pg} / \mathrm{ml}$. RIA was conducted in compliance with the protocol attached to the kit and as described before by Ko et al. (17). The assay was performed blind to the subject groups.

\section{Statistical analysis}

Plasma N/OFQ level means were compared between patient groups by Brown-Forsythe ANOVA accompanied by Games-Howell post hoc tests. The relationships of binary patient characteristic variables (coded by 0 and 1) with Plasma N/OFQ were studied by logit model. Factor analysis was used to classify patient characteristic variables together with plasma N/ OFQ and in order to reveal underlying hidden factors. Relationships between continuous patient characteristic variables and N/OFQ were explored by linear and nonlinear regression technique. Data are presented as median and interquartile range (IRQ). Statistical analyses were carried out by Statistica 8.0 (StatSoft Inc. Tulsa, OK, USA) and SPSS 15.0 (SPSS Inc. Chicago, IL, USA). The level of statistical significance was established at $\alpha=0.05$.

\section{Results}

Median (IQR) plasma N/OFQ levels were found as follows: $6.86(6.24-7.32) \mathrm{pg} / \mathrm{ml}$ for the group of enzyme positive acute coronary syndrome, $6.97(6.87-7.01) \mathrm{pg} / \mathrm{ml}$ for enzyme negative acute coronary syndrome and $7.58(7.23-8.20) \mathrm{pg} / \mathrm{ml}$ for ischemic heart diseases. We measured a level of $8.86(7.27-9.83) \mathrm{pg} / \mathrm{ml}$ in the control group. We did not detect any 
significant difference between N/OFQ levels measured in male and female subjects. Analysis of plasma N/OFQ levels in the control group showed a much wider interquartile range compared to the other three groups. Further investigations are needed to clarify whether or not healthy people can be divided into subgroups regarding the plasma N/OFQ levels.

Owing to the apparent heteroscedasticity (Fig. 1 showing the interquartile ranges) analysis of variances were performed by Brown-Forsythe ANOVA. The main effect for $\mathrm{N} / \mathrm{OFQ}$ was significant, $F(3,50.8)=21.6, p<0.000$. Post hoc tests revealed that N/OFQ was significantly lower in all cardiovascular patients compared to the control group (EPACS $p<0.000$, ENACS $p<0.000$, IHD $p=0.05$ ). Plasma N/OFQ levels in ischemic heart diseases at the same time were significantly higher than what we measured in enzyme positive acute coronary syndrome $(p=0.009)$ and in enzyme negative acute coronary syndrome $(p=0.012)$.

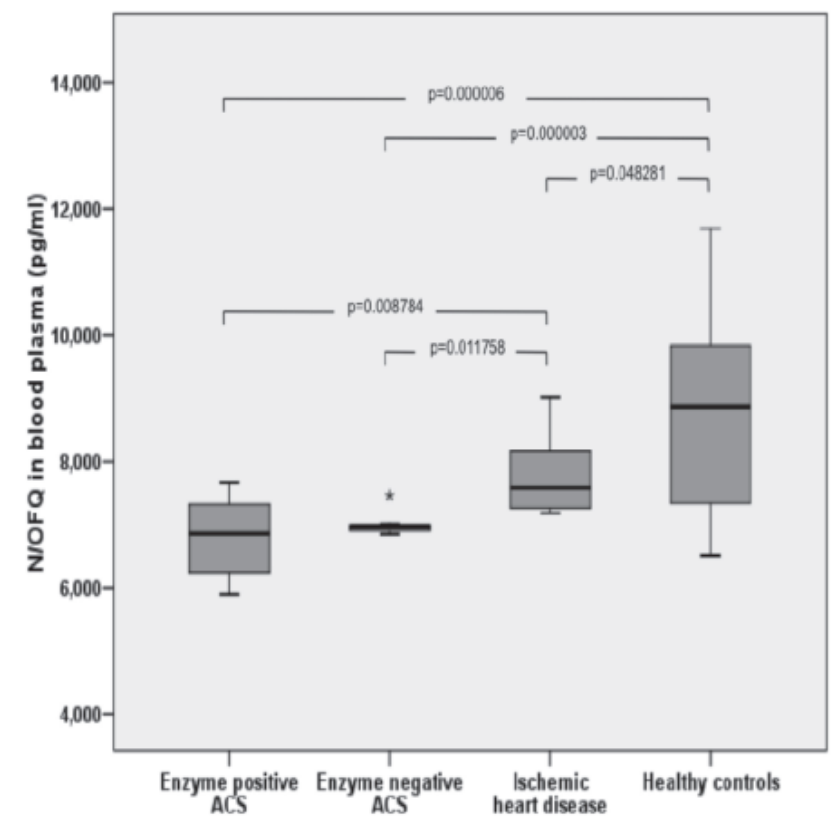

Fig. 1. Box and whisker plot of plasma N/OFQ levels show the median, minimum and maximum values and the interquartile ranges in the groups of enzyme positive ACS $(n=10)$, enzyme negative $\operatorname{ACS}(n=7)$, ischemic heart diseases $(n=11)$ and in healthy control subjects $(n=31)$

Statistical analyses of patient characteristics found the following variables also showing difference between the three patient groups (Table I). Age was significantly higher in the enzyme positive ACS group compared to enzyme negative ACS $(p=0.02)$. In spite of this age difference together with the fact that all of the patient group's ages were higher than that of the healthy control group's age is not a covariate, thus, there was no need to control for this variable in N/OFQ ANOVA. Laboratory results showed (Table II) that CK was significantly higher in the enzyme positive ACS group compared to enzyme negative ACS and to the ischemic heart disease group (both with $p=0.04$ ). Admission glucose level was significantly higher in the enzyme positive acute coronary syndrome compared to the other two groups 
( $p=0.03$ for ENACS and $p=0.04$ for OHD). LDH difference between EPACS and ENACS groups were also significant $(p=0.05)$. Echocardiography completed two days after admission showed that ejection fraction was significantly lower in the EPACS group compared to the ENACS $(p=0.016)$. Other patient characteristic variables did not show significant differences (Table II).

Table II. Clinical chemistry

\begin{tabular}{|c|c|c|c|}
\hline & $\begin{array}{c}\text { Enzyme positive ACS } \\
\qquad(n=10)\end{array}$ & $\begin{array}{c}\text { Enzyme negative ACS } \\
\qquad(n=7)\end{array}$ & $\begin{array}{c}\text { Ischemic heart disease } \\
\qquad(n=11)\end{array}$ \\
\hline Creatinine kinase (U/1) & $818.50(211.25-2861.50)$ & $132.00(81.50-148.00)^{*}$ & $95.00(89.50-110.25)^{*}$ \\
\hline $\mathrm{LDH}(\mathrm{U} / \mathrm{l})$ & $802.50(488.50-2475.00)$ & $399.00(333.00-483.50)^{*}$ & $552.00(319.25-673.75)$ \\
\hline CRP (mg/l) & $26.630(2.63-101.73)$ & $2.50(2.40-67.40)$ & $2.70(0.40-5.00)$ \\
\hline $\mathrm{HBDH}(\mathrm{U} / \mathrm{ml})$ & $347.50(230.25-1071.25)$ & $167.50(151.00-206.50)$ & $191.50(131.50-268.75)$ \\
\hline INR & $1.18(1.03-1.20)$ & $1.50(1.10-1.89)$ & $1.53(1.05-2.00)$ \\
\hline White blood cell count (G/1) & $10.50(6.23-19.08)$ & $9.60(7.40-13.20)$ & $6.80(5.30-10.00)$ \\
\hline Platelet count (G/l) & $214.50(160.00-254.25)$ & $223.00(165.50-290.00)$ & $214.00(201.00-230.00)$ \\
\hline $\mathrm{Hb}(\mathrm{g} / \mathrm{l})$ & $12.15(10.33-13.00)$ & $14.50(11.80-15.55)$ & $13.20(12.50-13.90)$ \\
\hline Serum sodium $(\mathrm{mmol} / \mathrm{l})$ & $141.00(137.75-142.75)$ & $143.00(140.50-146.50)$ & $138.00(137.00-141.00)$ \\
\hline Serum potassium $(\mathrm{mmol} / \mathrm{l})$ & $4.35(3.93-4.53)$ & $4.30(3.95-4.40)$ & $4.30(4.10-4.90)$ \\
\hline Cholesterol (mmol/1) & $5.00(2.50-5.55)$ & $4.45(4.40-5.25)$ & $3.90(3.35-4.55)$ \\
\hline Trygliceride (mmol/1) & $0.60(0.50-1.05)$ & $1.45(0.80-2.48)$ & $1.27(0.90-1.50)$ \\
\hline $\mathrm{LDL}(\mathrm{mmol} / \mathrm{l})$ & $4.10(1.40-4.90)$ & $3.30(3.30-4.00)$ & $2.80(2.80-3.20)$ \\
\hline $\mathrm{HDL}(\mathrm{mmol} / \mathrm{l})$ & $1.20(0.90-1.70)$ & $1.30(0.83-1.48)$ & $1.10(0.93-1.58)$ \\
\hline Admission glucose (mmol/l) & $11.45(6.25-17.45)$ & $5.20(5.03-6.43)^{*}$ & $5.70(4.78-7.50)^{*}$ \\
\hline Fasting glucose (mmol/1) & $6.40(4.85-9.25)$ & $6.25(4.80-7.70)$ & $5.70(5.70-5.70)$ \\
\hline $\operatorname{ALP}(\mathrm{U} / 1)$ & $177.50(92.25-193.00)$ & $254.50(171.50-302.25)$ & $187.00(134.50-253.00)$ \\
\hline GOT (U/1) & $35.00(24.75-208.50)$ & $20.00(17.50-23.50)$ & $23.00(18.75-27.25)$ \\
\hline GPT (U/l) & $24.00(17.50-44.50)$ & $18.00(14.50-33.00)$ & $19.50(13.50-33.00)$ \\
\hline Serum creatinine $(\mu \mathrm{mol} / \mathrm{l})$ & $95.50(79.50-244.25)$ & $90.00(65.50-118.50)$ & $109.00(81.00-178.00)$ \\
\hline Serum carbamide (mmol/1) & $9.00(5.38-19.13)$ & $6.30(4.90-10.35)$ & $6.60(5.25-10.33)$ \\
\hline $\begin{array}{l}\text { Nociceptin/orphanin FQ } \\
(\mathrm{pg} / \mathrm{ml})\end{array}$ & $6.86(6.24-7.32)$ & $6.97(6.87-7.01)$ & $7.58(7.23-8.20)^{* *}$ \\
\hline
\end{tabular}

Values are expressed as median (interquartile ranges) or as the number of patients (percentages).

$\mathrm{LDH}=$ lactate dehydrogenase; $\mathrm{CRP}=\mathrm{C}$-reactive protein; $\mathrm{HBDH}=$ hydroxybutyrate dehydrogenase; INR = International Normalized Ratio; $\mathrm{Hb}=$ hemoglobin; $\mathrm{LDL}=$ low-density lipoprotein cholesterol; $\mathrm{HDL}=$ high-density lipoprotein-cholesterol; ALP = alkaline phosphatase; GOT = glutamate oxaloacetate transaminase; GPT = glutamic pyruvic transaminase.

$P$ values show differences compared to the enzyme positive ACS group $(* p<0.05, * * p<0.01)$

Strong linear association was detected in the enzyme positive group between plasma N/OFQ levels and white blood cell (WBC) and platelet (PLT) count (Fig. 2, $r=0.93, p=$ 0.0001 for WBC, and 0.69 with $p=0.03$ for PLT) (Fig. 1). We noticed further significant 
correlations between N/OFQ levels of the subjects in the same group of enzyme positive ACS and creatine-kinase $(\mathrm{CK})$, and plasma cholesterol level (correlation coefficients and $p$ values were 0.73 with $p=0.02$ for CK, and -0.66 with $p=0.05$ for cholesterol) (Fig. 3). Significant nonlinear (power) regression was found between N/OFQ and glutamate oxaloacetate transaminase (GOT) in EPACS group $\left(R^{2}=0.49, p=0.03\right)$. N/OFQ has a nearly significant nonlinear (quadratic) association with C-reactive protein $(\mathrm{CRP})\left(R^{2}=0.629, p=0.07\right)$.
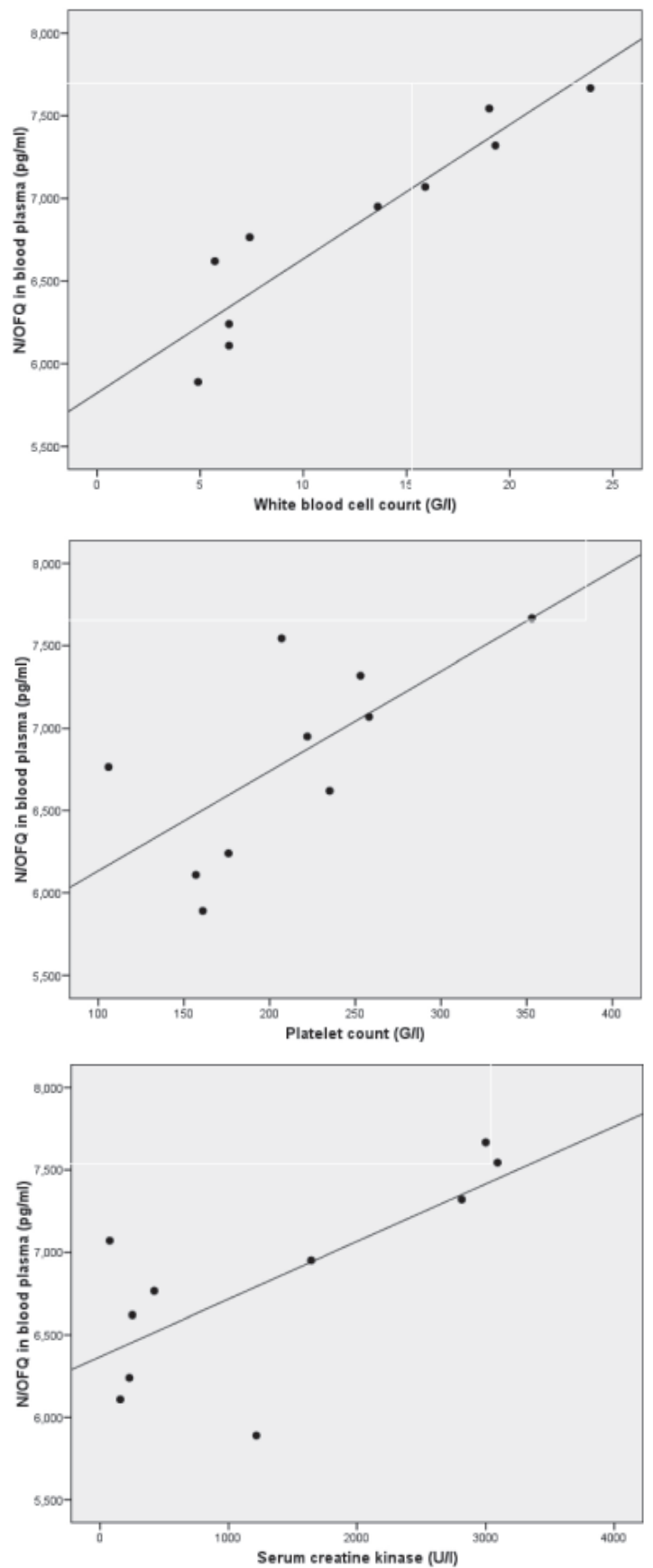

A

B

C

Fig. 2. Scatterplots showing the linear regression between the N/OFQ level and other laboratory parameters in the group of enzyme positive acute coronary syndrome (EPACS).

A: N/OFQ and WBC count $(r=0.93, p=0.0001)$.

B: N/OFQ and platelet count $(r=0.69, p=0.03)$.

C: N/OFQ and serum CK $(r=0.73, p=0.02)$ 

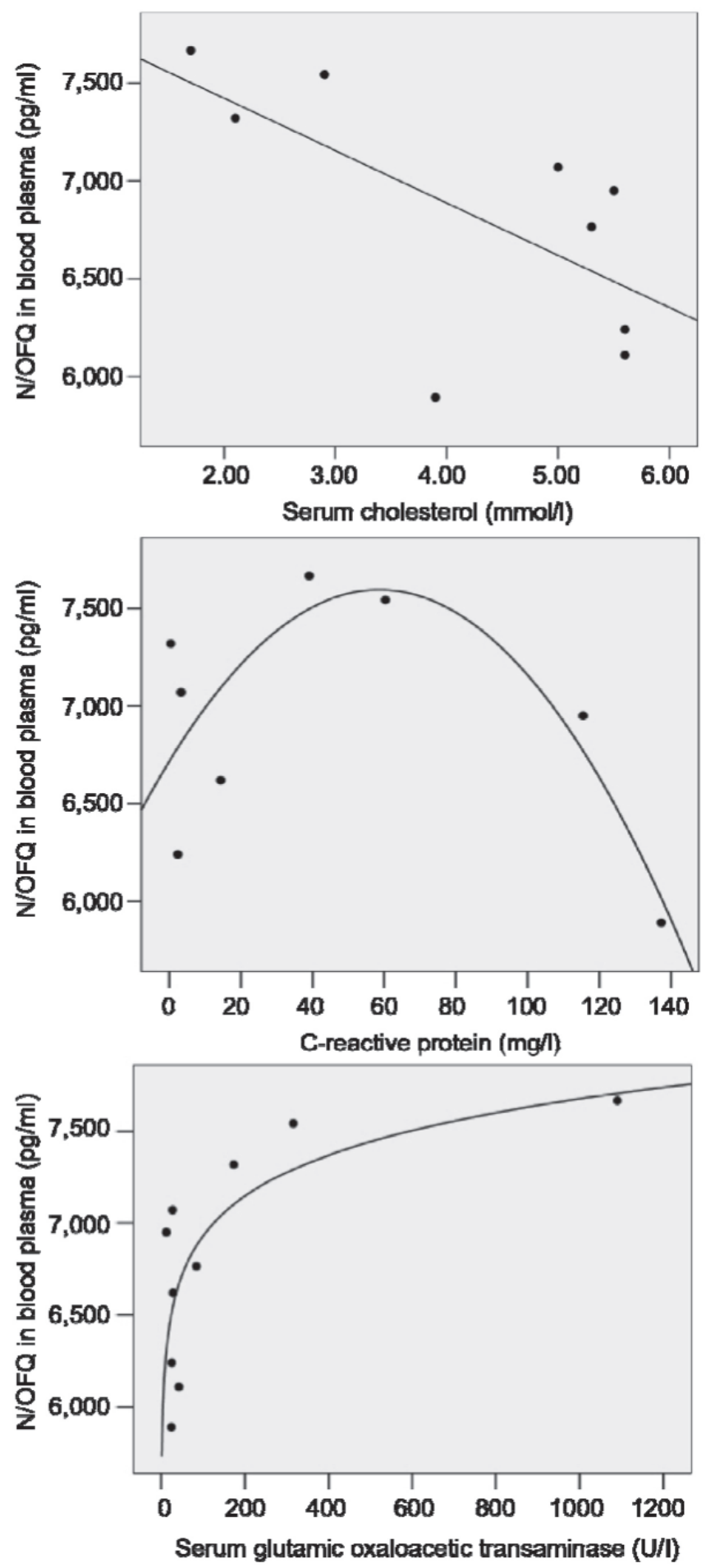

Fig. 3. Scatterplots showing the linear regression between A: N/OFQ and cholesterol $(r=-0.66, p=0.05)$ and nonlinear regression between B: N/OFQ and C-reactive protein $\left(R^{2}=0.629, p=0.07\right)$. C: N/OFQ and serum GOT $\left(R^{2}=0.49, p=0.03\right)$.

Outliers are not shown 
Based on the N/OFQ level measured in patient groups two binary variables could be predicted, pain and necroenzyme efflux, using logistic regression. Low N/OFQ level predicted pain $\left(\mathrm{Chi}^{2}=27.5, d f=1, p<0.000\right)$ and necroenzyme efflux $\left(\mathrm{Chi}^{2}=7.8, d f=1, p=0.005\right)$.

Exploratory factor analysis classified the 25-patient characteristic variable together with the plasma N/OFQ into three factors, which explain nearly equal proportions of the total variance. The factors represent common underlying hidden phenomena and are responsible for the covariation between the observed variables. The first latent factor has an $r=0.92$ correlation with N/OFQ and the other variables in this factor are INR, platelet count, TG, SGOT and SGPT. The members of the second factor are age, heart rate, CRP, Hb, cholesterol, HDL, GGT, creatinine and urea. The third factor consists of the following patient characteristic variables: systolic blood pressure, serum CK, LDH, HBDH, EF, LDL, GLC admission and ALP.

\section{Discussion}

We noticed significantly lower plasma nociceptin/orphanin FQ levels in acute coronary syndrome patients after coronarography compared to healthy volunteers. Our results show that ACS is attached to the lowest levels of N/OFQ among the three disease groups examined. We found correlation between N/OFQ and GOT level in ACS as well. This finding suggests that N/OFQ levels of the plasma depends not only on the actual level of pain, but is very much dependent on whether there is an ischemic injury or not, followed by necrosis.

In our previous studies, we have shown that chronic ischemic heart disease patients, suffering from chronic angina pectoris, have decreased nociceptin/orphanin FQ levels compared to healthy volunteers (18). We also have concluded that the severity of the atherosclerosis in the heart is in inverse relationship with circulating N/OFQ levels. In an elegant study, Fontana et al. (11) found that N/OFQ levels were elevated in patients with unstable angina. The authors implicated that higher nociceptin levels were due to repeated spontaneous episodes of angina. They also accomplished a plausible stress test with adenosine infusion, which showed that induced myocardial ischemia does not have any effect on the plasma N/OFQ levels. In our study, we noticed that enzyme positive acute coronary syndrome is attached to a lower level of N/OFQ compared to enzyme negative ACS, although the difference did not reach the level of significance. We also have found that after ACS, nociceptin levels are significantly correlated with higher GOT levels during the cardiac ischemia-necrosis. However, all these findings are not in contradiction with the important study of Fontana et al. (11), since our patients were examined for nociceptin two days after the onset of acute coronary syndrome and their symptoms abolished after undergoing PCI. However, our results indicate that not only pain, but acute ischemic injury/necrosis also plays a role in the regulation of N/OFQ, as the only difference between enzyme positive ACS and the other disease groups was the presence of the acute ischemic injury in the heart.

We found a negative correlation between plasma nociceptin and cholesterol levels in the EPACS group. This result is in possible contradiction with recent studies, where intracerebroventricular nociceptin treatment was shown to increase cholesterol levels in mice (20). Stressful stimuli have also been shown to elevate total plasma cholesterol levels and activate endogenous opioid systems (4). Further studies are needed for explaining the relationship between plasma nociceptin and cholesterol levels during acute stress in humans. Guo et al. (13) noticed that myocardial ischemia up-regulated N/OFQ in dorsal root ganglia and spinal cord of rats. These interesting findings are in line with our results, although the possible correlation of neural and blood plasma N/OFQ levels have not been examined yet. 
Stamer et al. (23) found lower pN/OFQ expression in the peripheral blood cells (PBC) of end-stage cancer patients and septic patients compared with healthy controls. They also showed that increased plasma procalcitonin, a marker of inflammation, was associated with decreased $\mathrm{pN} / \mathrm{OFQ}$ in all patient groups. However, NOP expression was upregulated in the same patient groups. The same study included postoperative patients with acute surgical stress. Interestingly, changes in postoperative patients were found to be minor compared to septic and cancer patients.

Plasma N/OFQ levels proved to be also elevated in ischemic stroke and transient ischemic attack patients (25). The conclusion of the study was that the increase in N/OFQ levels is the consequence of the neural ischemic injury. This finding also confirmed that ischemic injury is in connection with the N/OFQ levels.

Human studies carried out on females in the luteal phase suffering in fibromyalgia syndrome have shown that N/OFQ level is linked to sex hormones (2). This is in agreement with the result of a previous in vitro study, which has shown that estrogen up-regulates the transcription of the N/OFQ precursor (29). Human studies having been made so far have not found any significant difference between male and female patients suffering from cluster headache or from bipolar disorders $(10,26)$. We can affirm this statement, as we did not find any significant difference between male and female subjects either in the patients' groups or the controls.

We found significant correlations of N/OFQ and white blood cell counts, which provide further evidence of N/OFQ being regulated by immune cells beside the nervous system. The strong correlation between WBC and platelet counts and nociceptin levels suggest that plasma nociceptin levels might be WBC and platelet derived in ACS. Previous findings of studies made on rodents have shown both in vivo and in vitro that the NOP receptor and N/ OFQ are expressed on peripheral mononuclear cells and neutrophils $(1,27)$. The connection between N/OFQ and inflammation has been also confirmed in a human study conducted on critically ill patients with sepsis (28). Plasma N/OFQ concentrations were found higher in patients who died within 30 days compared to survivors, however no correlation was detected between plasma N/OFQ concentrations and markers of illness severity and organ dysfunction. How decreased plasma nociceptin/orphanin FQ levels after acute coronary syndromes affect immune/ inflammatory functions remains to be further elucidated. It is not obvious whether lower N/OFQ levels would mean impaired immune functions after ACS, since WBC nociceptin receptor expression levels have not yet been investigated during acute cardiac ischemia/reperfusion. However, temporary impairment of immune functions could be beneficial by modulating the healing process of the myocardium after an acute ischemic event.

Study limitations: The major limitation of our study is the relatively small number of the whole patient cohort. However, this is the first, small number investigation related to ischemia/necrosis and plasma nociceptin/orphanin FQ levels after acute myocardial infarction. Further investigations are needed and a larger number of acute coronary syndrome cohorts with differing extents of the disease should be investigated in the future to confirm the novel findings of our study.

Our findings indicate that the presence of acute coronary syndromes is closely associated with lower plasma N/OFQ levels after coronarography. Both enzyme positive and negative ACS are attached to a very low level of plasma N/OFQ, even compared to quiescent ischemic heart diseases. As we found correlation between N/OFQ and CK and WBC count in the enzyme positive ACS group, it seems that not only pain sensation, but also ischemic injury 
and the concomitant inflammatory response may have a role in regulating the plasma level of N/OFQ. Further studies are needed to examine the relevance and effects of acute ischemic stress on the N/OFQ system and to decide whether the lower N/OFQ level is a cause or a consequence of the acute ischemic heart disease.

\section{Acknowledgement}

This work was sponsored by the Hungarian Ministry of Health (ETT 045/2009).

\section{REFERENCES}

1. Acosta C, Davies A: Bacterial lipopolysaccharide regulates nociceptin expression in sensory neurons. J. Neurosci. Res. 86, 1077-1086 (2008)

2. Anderberg UM, Liu Z, Berglund L, Nyberg F: Plasma levels on nociceptin in female fibromyalgia syndrome patients. Z. Rheumatol. 57 Suppl. 2, 77-80 (1998)

3. Anderson JL, Adams CD, Antman EM, Bridges CR, Califf RM, Casey DE Jr., Chavey WE, 2nd, Fesmire FM, Hochman JS, Levin TN, Lincoff AM, Peterson ED, Theroux P, Wenger NK, Wright RS, Smith SC, Jr., Jacobs AK, Halperin JL, Hunt SA, Krumholz HM, Kushner FG, Lytle BW, Nishimura R, Ornato JP, Page RL, Riegel B: ACC/AHA 2007 guidelines for the management of patients with unstable angina/non-ST-Elevation myocardial infarction: a report of the American College of Cardiology/American Heart Association Task Force on Practice Guidelines (Writing Committee to Revise the 2002 Guidelines for the Management of Patients With Unstable Angina/Non-ST-Elevation Myocardial Infarction) developed in collaboration with the American College of Emergency Physicians, the Society for Cardiovascular Angiography and Interventions, and the Society of Thoracic Surgeons endorsed by the American Association of Cardiovascular and Pulmonary Rehabilitation and the Society for Academic Emergency Medicine. J. Am. Coll. Cardiol. 50, e1-e157 (2007)

4. Bryant HU, Story JA, Yim GK: Assessment of endogenous opioid mediation in stress-induced hypercholesterolemia in the rat. Psychosom. Med. 50, 576-585 (1988)

5. Bunzow JR, Saez C, Mortrud M, Bouvier C, Williams JT, Low M, Grandy DK: Molecular cloning and tissue distribution of a putative member of the rat opioid receptor gene family that is not a mu, delta or kappa opioid receptor type. FEBS Lett. 347, 284-288 (1994)

6. Chu X, Xu N, Li P, Wang JQ: Profound inhibition of cardiomotor neurons in the rat rostral ventrolateral medulla by nociceptin (orphanin FQ). Neuroreport 9, 1081-1084 (1998)

7. Czapla MA, Champion HC, Kadowitz PJ: Decreases in systemic arterial and hindquarters perfusion pressure in response to nociceptin are not inhibited by naloxone in the rat. Peptides 18, 1197-1200 (1997)

8. Czapla MA, Champion HC, Kadowitz PJ: Nociceptin, an endogenous ligand for the ORL1 receptor, has vasodilator activity in the hindquarters vascular bed of the rat. Peptides 18, 793-795 (1997)

9. Ertsey C, Hantos M, Bozsik G, Tekes K: Plasma nociceptin levels are reduced in migraine without aura. Cephalalgia 25, 261-266 (2005)

10. Ertsey C, Hantos M, Bozsik G, Tekes K: Circulating nociceptin levels during the cluster headache period. Cephalalgia 24, 280-283 (2004)

11. Fontana F, Bernardi P, Pizzi C, Spampinato S, Bedini A, Pich EM: Plasma nociceptin/orphanin FQ levels rise after spontaneous episodes of angina, but not during induced myocardial ischemia. Peptides 30, 1705-1709 (2009)

12. Gumusel B, Hao Q, Hyman A, Chang JK, Kapusta DR, Lippton H: Nociceptin: an endogenous agonist for central opioid like1 (ORL1) receptors possesses systemic vasorelaxant properties. Life Sci. 60, PL141-145 (1997)

13. Guo Z, Yao TP, Wang JP, Ding JY: Acute myocardial ischemia up-regulates nociceptin/orphanin FQ in dorsal root ganglion and spinal cord of rats. Neurosci. Lett. 433, 274-278 (2008)

14. Hantos MB, Szalay F, Lakatos PL, Hegedus D, Firneisz G, Reiczigel J, Torok T, Tekes K: Elevated plasma nociceptin level in patients with Wilson disease. Brain Res. Bull. 58, 311-313 (2002)

15. Horvath A, Folhoffer A, Lakatos PL, Halosz J, Illyes G, Schaff Z, Hantos MB, Tekes K, Szalay F: Rising plasma nociceptin level during development of HCC: a case report. World J. Gastroenterol. 10, 152-154 (2004) 
16. Kapusta DR: Neurohumoral effects of orphanin FQ/nociceptin: relevance to cardiovascular and renal function. Peptides 21, 1081-1099 (2000)

17. Ko MH, Kim YH, Woo RS, Kim KW: Quantitative analysis of nociceptin in blood of patients with acute and chronic pain. Neuroreport 13, 1631-1633 (2002)

18. Krepuska M, Sotonyi P, Csobay-Novak C, Szeberin Z, Hartyanszky I, Zima E, Szilagyi N, Horkay F, Merkely B, Acsady G, Tekes K: Plasma nociceptin/orphanin FQ levels are lower in patients with chronic ischemic cardiovascular diseases-A pilot study. Regul. Pept. 169, 1-5 (2011)

19. Lambert DG: The nociceptin/orphanin FQ receptor: a target with broad therapeutic potential. Nat. Rev. Drug Discov. 7, 694-710 (2008)

20. Matsushita H, Ishihara A, Mashiko S, Tanaka T, Kanno T, Iwaasa H, Ohta H, Kanatani A: Chronic intracerebroventricular infusion of nociceptin/orphanin FQ produces body weight gain by affecting both feeding and energy metabolism in mice. Endocrinology 150, 2668-2673 (2009)

21. Mollereau C, Parmentier M, Mailleux P, Butour JL, Moisand C, Chalon P, Caput D, Vassart G, Meunier JC: ORL1, a novel member of the opioid receptor family. Cloning, functional expression and localization. FEBS Lett. 341, 33-38 (1994)

22. Reinscheid RK, Nothacker HP, Bourson A, Ardati A, Henningsen RA, Bunzow JR, Grandy DK, Langen H, Monsma FJ, Jr., Civelli O: Orphanin FQ: a neuropeptide that activates an opioidlike G protein-coupled receptor. Science 270, 792-794 (1995)

23. Stamer UM, Book M, Comos C, Zhang L, Nauck F, Stuber F: Expression of the nociceptin precursor and nociceptin receptor is modulated in cancer and septic patients. Br. J. Anaesth. 106, 566-572 (2011)

24. Tekes K, Gyenge M, Sotonyi P, Csaba G: Effect of neonatal nociceptin or nocistatin imprinting on the brain concentration of biogenic amines and their metabolites. Brain Dev. 31, 282-287 (2009)

25. Tekes K, Hantos M, Bator G, Gyenge M, Laufer R, Folyovich A: Endogenous nociceptin level in ischemic stroke: connection to serotonin system. Neuropsychopharmacol. Hung. 8, 53-59 (2006)

26. Wang LN, Liu LF, Zhang JX, Zhao GF: Plasma levels of nociceptin/orphanin FQ in patients with bipolar disorders and health adults. Zhonghua Yi Xue Za Zhi. 89, 916-918 (2009)

27. Williams JP, Thompson JP, McDonald J, Barnes TA, Cote T, Rowbotham DJ, Lambert DG: Human peripheral blood mononuclear cells express nociceptin/orphanin FQ, but not mu, delta, or kappa opioid receptors. Anesth. Analg. 105, 998-1005, table of contents (2007)

28. Williams JP, Thompson JP, Young SP, Gold SJ, McDonald J, Rowbotham DJ, Lambert DG: Nociceptin and urotensin-II concentrations in critically ill patients with sepsis. Br. J. Anaesth. 100, 810-814 (2008)

29. Xie GX, Ito E, Maruyama K, Suzuki Y, Sugano S, Sharma M, Pietruck C, Palmer PP: The promoter region of human prepro-nociceptin gene and its regulation by cyclic AMP and steroid hormones. Gene 238, 427-436 (1999) 